\title{
Resolution of headache after reduction of prolactin levels in hyperprolactinemic patients
}

\author{
Resolução de cefaleia após redução dos níveis de prolactina em pacientes com \\ hiperprolactinemia \\ Miriam da Costa OLIVEIRA ${ }^{1,2}$, Liselotte Menke BAREA ${ }^{3}$, Andreia Peres Klein HORN², Bárbara Roberta \\ ONGARATTI', José Otávio Dworzeki SOARES³, Bruna ARAUJO², Tainá Mafalda dos SANTOS², \\ Carolina Leães RECH², Júlia Fernanda Semmelmann PEREIRA-LIMA',2
}

\begin{abstract}
Prolactin (PRL) secreting adenomas are associated with high incidence of headache. The role of hyperprolactinemia in the headache context is not clear, nor is the effect of its treatment on headache. Methods: The present longitudinal study evaluated hyperprolactinemic patients (69), in terms of presence and characteristics of headache before and after hyperprolactinemia treatment. Results: Headache was reported by 45 (65.2\%) patients, independent of the etiology of hyperprolactinemia. The migraine phenotype was the most prevalent (66.6\%). Medications used in the treatment of headache not changed during the study. The first line of treatment of hyperprolactinemia was dopaminergic agonists. In the last reevaluation, PRL level under treatment was within the reference range in $54.7 \%$ of the cases, and it was observed complete or partial resolution of the headache in $75 \%$ of the cases. The median PRL at this time in patients with complete headache resolution was $17 \mathrm{ng} / \mathrm{mL}$, in those who reported partial recovery was $21 \mathrm{ng} / \mathrm{mL}$, and in those in whom the headache did not change was $66 \mathrm{ng} / \mathrm{mL}$, with a significant difference between the group with complete headache resolution vs. the group with unchanged headache $(p=0.022)$. In the cases with complete headache resolution, the median fall on PRL levels was $89 \%$ and in those cases with partial headache resolution $86 \%$, both significantly different $(p<0.001)$ from the fall in the cases with an unchanged headache. Conclusion: Data allow us to conclude that, in this series, in the majority of cases the reduction in the level of PRL was followe3d by cessation or relief of the pain.
\end{abstract}

Keywords: headache; pituitary adenomas; prolactin; hyperprolactinemia; dopaminergic agonist.

RESUMO

Os adenomas secretores de prolactina (PRL) estão associados à alta incidência de cefaleia. 0 papel da hiperprolactinemia no contexto da dor de cabeça não está claro, nem o efeito da redução dos níveis da PRL na cefaleia. Métodos: O presente estudo longitudinal avaliou pacientes hiperprolactinêmicos (69), quanto à presença e às características da cefaleia antes e após o tratamento da hiperprolactinemia. Resultados: Cefaleia foi relatada por 45 (65,2\%) pacientes, independente da etiologia da hiperprolactinemia. 0 fenótipo de enxaqueca foi mais prevalente (66,6\%). Os medicamentos usados no tratamento da cefaleia não foram alterados durante o estudo. A primeira linha de tratamento da hiperprolactinemia foram os agonistas dopaminérgicos. Na última reavaliação, o nível de PRL sob tratamento estava dentro da faixa de referência em $54,7 \%$ dos casos, observando-se resolução completa ou parcial da cefaleia em $75 \%$ dos casos. A mediana de PRL neste momento em pacientes com resolução completa da cefaleia foi de $17 \mathrm{ng} / \mathrm{mL}$, nos que relataram recuperação parcial foi de $21 \mathrm{ng} / \mathrm{mL}$, e naqueles em que a cefaleia não se alterou foi de $66 \mathrm{ng} / \mathrm{mL}$, com uma diferença significativa entre o grupo com resolução completa da cefaleia versus o grupo com cefaleia inalterada $(p=0,022)$. Nos casos com resolução completa da cefaleia, a queda mediana nos níveis de PRL foi de $89 \%$ e nos casos com resolução parcial de cefaleia de $86 \%$, ambos significativamente diferentes ( $p<0,001)$ da queda nos casos com cefaleia inalterada. Conclusão: Os dados permitem concluir que, nesta série, na maioria dos casos, a redução do nível de PRL foi seguida pela cessação ou alívio da dor.

Palavras-chave: cefaleia; adenomas hipofisários; prolactina; hiperprolactinemia; agonista dopaminérgico.

\footnotetext{
'Universidade Federal de Ciências da Saúde de Porto Alegre, Programa de Pós-Graduação em Patologia, Porto Alegre RS, Brazil.

${ }^{2}$ Irmandade Santa Casa de Misericórdia de Porto Alegre, Centro de Neuroendocrinologia, Porto Alegre RS, Brazil.

${ }^{3}$ Universidade Federal de Ciências da Saúde de Porto Alegre, Departamento de Neurologia, Porto Alegre RS, Brazil.
}

Miriam da Costa OLIVEIRA iD https://orcid.org/0000-0002-7091-513X; Liselotte Menke BAREA iD https://orcid.org/0000-0002-9531-9115;Andreia Peres Klein HORN (iD https://orcid.org/0000-0003-1621-3468; Bárbara Roberta ONGARATTI iD https://orcid.org/0000-0002-7953-2952; José Otávio Dworzeki SOARES ID https://orcid.org/0000-0001-6204-0049; Bruna ARAUJO iD https://orcid.org/0000-0002-9443-9924;Tainá Mafalda dos SANTOS iD https://orcid.org/0000-0002-2243-6919; Carolina Leães RECH iD https://orcid.org/0000-0003-4603-6968; Júlia Fernanda Semmelmann PEREIRALIMA iD https://orcid.org/0000-0001-8207-9119

Correspondence: Miriam da Costa Oliveira; Universidade Federal de Ciências da Saúde de Porto Alegre; Rua Sarmento Leite, 245 ; $90050-170$ Porto Alegre RS, Brazil; E-mail:mco@ufcspa.edu.br

Conflicts of interest: There is no conflict of interest to declare.

Received on May 06, 2019; Received in final form on August 26, 2019; Accepted on September 12, 2019. 
Headache is a common manifestation of pituitary diseases, particularly in adenomas ${ }^{1-3}$, especially the prolactinsecreting adenomas. The headache has its origins in many factors, isolated or combined, including tumor extension, invasion of perisellar structures, personal predisposition, family history, and hormonal alterations in the hypothalamus-pituitary axis ${ }^{4}$. However, it is not clear if the headache is a functional or structural consequence of pituitary disease ${ }^{5}$. Some evidences point out that hyperprolactinemia per se could interfere in the development of pain by neuro-sensorial modulation ${ }^{6}$. The present study goal was to evaluate the headache frequency in patients with hyperprolactinemia of distinct etiologies and to observe the headache evolution after hyperprolactinemia treatment.

\section{METHODS}

The study was approved by the Institutional Committee on Ethics and Research (no 0012/2012) and conducted in accordance with the Helsinki Declaration. The patients were included through the signature of Free and Informed Consent Term.

It was conducted a longitudinal study among patients with hyperprolactinemia, regardless of previous treatment, attended in a Neuroendocrinology Unit in a referral hospital in southern Brazil. Prolactin (PRL) values above $17.7 \mathrm{ng} / \mathrm{mL}$ for men and above $29.2 \mathrm{ng} / \mathrm{mL}$ for women were considered hyperprolactinemia. The cases with macroprolactin excess were excluded. Pituitary adenomas characteristics, as size and presence of local invasion, were determined by magnetic resonance. Of the patients with macroprolactinoma, 10 invaded the cavernous and/or sphenoidal sinus.

The sample was constituted by 69 patients, 51 females, with a mean age of 43 years for men and 51 years for women. Concerning the hyperprolactinemia etiology, 48 (69.5\%) patients presented prolactin-secreting adenomas, 29 of them macroadenomas and 19 microadenomas. Other nine patients presented hyperprolactinemia: associated with medication (4), polycystic ovary syndrome (1), non-functioning macroadenomas (2), one retro-clivoid meningioma, and one Rathke's cleft cyst. In the remaining 12 cases, the origin of hyperprolactinemia was considered idiopathic. The patients with adenoma were previously evaluated in relation to the pituitary hormonal axes and received adequate replacement, except for growth hormone $(\mathrm{GH})$.

The patients were submitted to a complete neurological examination and a questionnaire related to the headache and its clinical characteristics: frequency and intensity, presence of associated symptoms (nausea, vomit, photophobia, phonophobia, osmophobia, and diarrhea), family history, as well the use of medication to treat or prevent headache. Patients with headache constituted Group I and those without headache Group II. The headache type was classified according to the International Headache Society Classification (IHS: ICHD-3 beta 2013) ${ }^{7}$. The patients of Group I were reevaluated in terms of maintenance and pattern of headache at least six months after the first evaluation, after or during the hyperprolactinemia treatment. The headache medication used before the inclusion of the patient in the study remained unchanged until headache reevaluation. Hyperprolactinemia treatment was prescribed according to its etiology and clinical repercussion, following endocrine guidelines ${ }^{8}$ and the particularities of each patient.

Due to the rupture with gaussian assumptions, quantitative data were described by median and minimum and maximum value. The group comparisons were made using the Kruskal-Wallis $\mathrm{H}$ test, followed by post-hoc comparisons. Comparisons of the proportional values from prolactin quantitative suppression presented symmetric distribution and were summarized by median and standard deviation, then compared among the groups by variance analysis (ANOVA) and followed by Tukey test. Values lower than $\mathrm{p}<0.05$ were considered statistically significant. Data were analyzed using SPSS program (version 22.0).

\section{RESULTS}

Group I was composed of 36 women and 9 men, with $42.6 \pm 14.7$ years, and Group II by 15 women and 9 men, with $48.8 \pm 16$ years.

The interval between the initial diagnosis of hyperprolactinemia and the beginning of the study was less than one year in 7 cases, between 1 and 5 years in 21 cases and more than 5 years in 41 cases. The PRL value at the patient's entry in the study varied from 33 to $6562 \mathrm{ng} / \mathrm{mL} ; 17$ patients presented PRL level lower than $100 \mathrm{ng} / \mathrm{mL}, 20$ between 101 and 200 ng/mL, and 32 higher than $200 \mathrm{ng} / \mathrm{mL}$. The median PRL in those patients with macroadenomas was $488 \mathrm{ng} / \mathrm{mL}$, in those with microadenomas $153 \mathrm{ng} / \mathrm{mL}$ and in hyperprolactinemia from other etiologies $90 \mathrm{ng} / \mathrm{mL}$, is the median measure of macroadenomas significantly higher than microadenomas and other hyperprolactinemias $(\mathrm{p}<0.001)$.

Headache was reported by 45 patients $(65.2 \%$ of the total sample), 21 patients (46.6\%) with PRL secreting macroadenomas, 13 (29\%) with microadenomas, and 11 (24.4\%) with hyperprolactinemia from other etiologies. In patients with pituitary macroadenomas, headache frequency was $72.4 \%$, in those with microadenomas was $68.4 \%$, and in the others was $52.4 \%$. The headache frequency did not vary significantly among the different etiologies $(\mathrm{p}=0.32)$. The median PRL in Group I was $201 \mathrm{ng} / \mathrm{mL}(38-5464 \mathrm{ng} / \mathrm{mL})$ and in Group II was $162 \mathrm{ng} / \mathrm{mL}$ (33-6562 ng/mL). Among the macroadenomas associated to headache, 8 invaded cavernous and/ or sphenoidal sinus. Of the women with headache, 10 were aged between 50 and 75 years, 9 of whom had hypogonadism, either physiological (menopause) or pathological, due 
to central hypogonadism due to hyperprolactinemia itself or hypopituitarism associated with the tumor mass. Concerning headache classification, 31 (68.8\%) met the criteria for migraine phenotype, $8(17.7 \%)$ for tension-type headache, and $6(13.3 \%)$ could not be classified. Thirty-four patients used specific medication to treat headache, according to previous medical orientation.

Of the total sample, $12(17.5 \%)$ patients were not submitted to treatment, all of them with hyperprolactinemia not related to pituitary adenoma and without clinical repercussion. During follow-up, 39 (56.5\%) patients used dopaminergic agonist (DA agonist) alone; 18 (26\%) were submitted to pituitary surgery, followed in 5 cases by radiotherapy and/ or in 15 cases by DA agonist. The agonists used were bromocriptine and cabergoline, in conventional doses, adjusted according to the patient needs. We did not have access to the final PRL dosage of four patients (two from Group I and two from Group II), although they completed the neurological exam and the questionnaire. The final PRL level, available in 53 cases, showed normalization in 29 patients $(54.7 \%)$. In the reevaluation, the median PRL was $25 \mathrm{ng} / \mathrm{mL}$ (0.3-2859 ng/ $\mathrm{mL}$ ) and, in $57 \%$ of the cases, less than $30 \mathrm{ng} / \mathrm{mL}$. The final median PRL of Group I ( $\mathrm{n}=43$ ) was $21 \mathrm{ng} / \mathrm{mL}$ (3-335 ng/mL) and of Group II (n=22) was 29 ng/mL (0.3-2859 ng/mL). After treatment, the median PRL of both groups were very similar and did not show significant differences $(\mathrm{p}=0.835)$.

Of the 45 patients at the end of the evaluation, two had no recent evaluation of PRL level, remaining 43 patients for PRL revaluation (Table 1); another one did not complete the questionnaire on headache, remaining 44 patients for analysis of the evolution of pain. It was observed resolution or improvement of pain in 33 of them (75\%): complete in 19 patients and partial in 14. The absence of episodes of headache was considered as resolution of pain. Reports of pain decrease in intensity or frequency of the condition were considered as improvement. Maintenance of the initial presentation of headache was considered unchanged headache. Complete resolution of headache occurred in 16 women and 3 men, with $44.4 \pm 14.3$ years; with partial resolution, 10 women and 4 men, $41.7 \pm 11.6$ years; without resolution, 10 women and 2 men, $41 \pm 18.9$ years.

Among reevaluated patients, 19 still had hyperprolactinemia (30 to $355 \mathrm{ng} / \mathrm{mL}$ ). This may be associated to the absence of treatment or loss of dose adjustment of

Table 1.PRL Variation.

\begin{tabular}{|c|c|c|c|c|}
\hline Headache status & Case & $\begin{array}{l}\text { PRL First Evaluation } \\
(\mathrm{ng} / \mathrm{mL})\end{array}$ & $\begin{array}{l}\text { PRL Revaluation } \\
\text { (ng/mL) }\end{array}$ & $\begin{array}{l}\text { PRL Reduction } \\
(\%)\end{array}$ \\
\hline \multirow{19}{*}{$\begin{array}{l}\text { Complete headache } \\
\text { resolution } \\
\text { (Subgroup I) }\end{array}$} & 1 & 2639 & 30 & 98.9 \\
\hline & 2 & 610 & 116 & 81.0 \\
\hline & 3 & 204 & 33 & 83.8 \\
\hline & 4 & 76 & 33 & 56.6 \\
\hline & 5 & 75 & 29 & 61.3 \\
\hline & 6 & 117 & 4 & 96,5 \\
\hline & 7 & 885 & 6 & 99.3 \\
\hline & 8 & 127 & 10 & 91.7 \\
\hline & 9 & 185 & 10 & 94.2 \\
\hline & 10 & 301 & 10 & 96.4 \\
\hline & 11 & 174 & 12 & 93.1 \\
\hline & 12 & 5001 & 14 & 99.7 \\
\hline & 13 & 368 & 14 & 96.0 \\
\hline & 14 & 1001 & 16 & 98.4 \\
\hline & 15 & 201 & 17 & 91.4 \\
\hline & 16 & 1308 & 17 & 98.7 \\
\hline & 17 & 150 & 18 & 88.0 \\
\hline & 18 & 153 & 19 & 87.5 \\
\hline & 19 & 111 & 21 & 81.1 \\
\hline
\end{tabular}




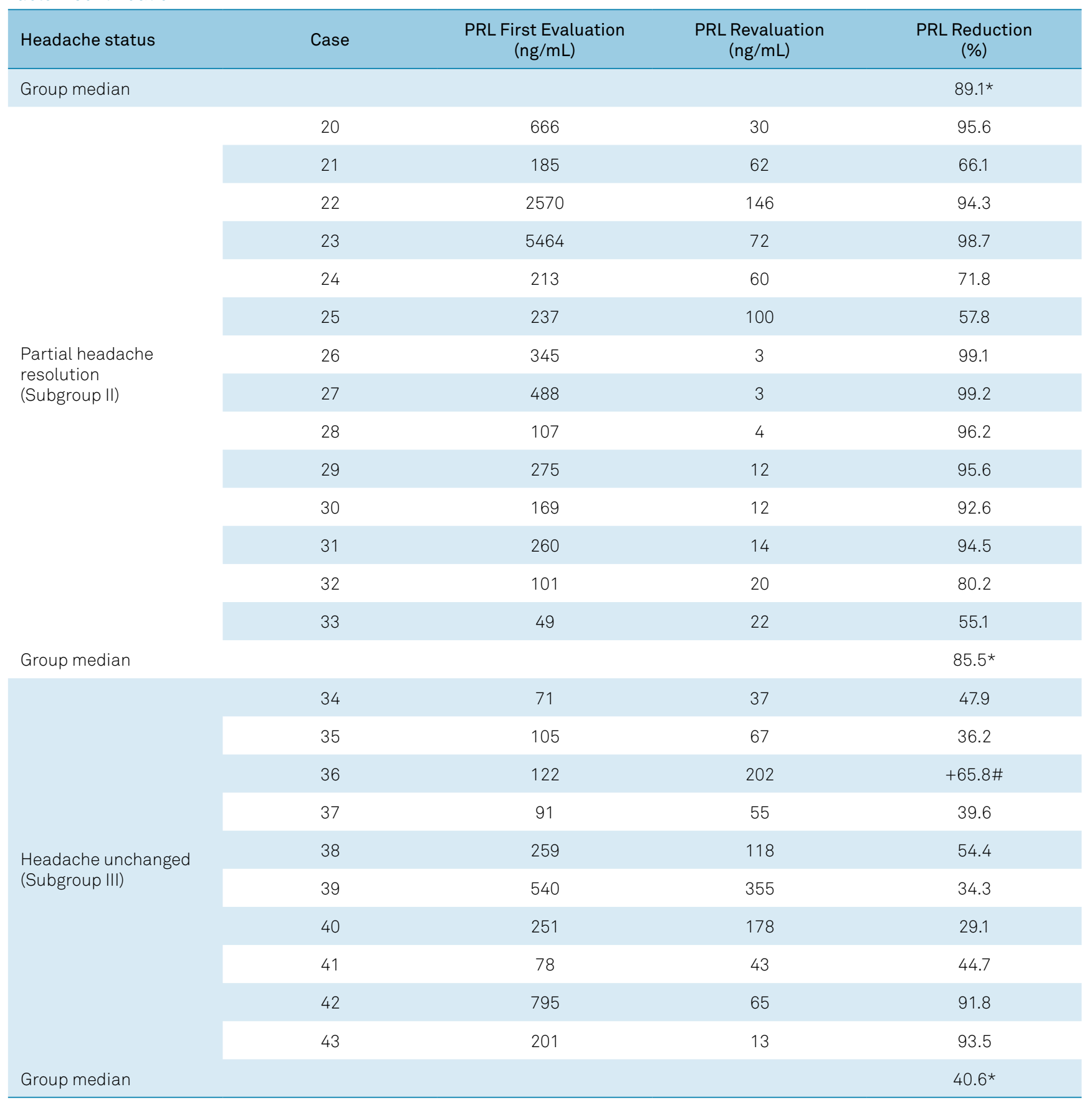

\#The percentage represents an increase in the prolactin (PRL) level; * significant difference between subgroup I versus III and subgroup II versus III (p<0.001).

medication, due to lack of clinical repercussion of hyperprolactinemia and modest elevation of PRL levels; to irregularity in medication use; to a short time after radiotherapy; and rarely due to the difficulty in normalizing the level of PRL with a conventional dose of DA agonist. In the group reevaluated for headache, all those who normalized PRL used the DA agonist, while in those who remained hyperprolactinemic, $83.3 \%$ used DA agonist.

The median initial PRL in the patients with complete headache resolution $(\mathrm{n}=19)$ was $201 \mathrm{ng} / \mathrm{mL}$, in those with partial headache resolution ( $\mathrm{n}=14)$ was $249 \mathrm{ng} / \mathrm{mL}$, and in those with unchanged headache $(\mathrm{n}=11)$ was $122 \mathrm{ng} / \mathrm{mL}$. In the reevaluation, the median final PRL was $17 \mathrm{ng} / \mathrm{mL}$ in those patients with complete headache resolution, $21 \mathrm{ng} /$ $\mathrm{mL}$ in those with partial resolution, and $66 \mathrm{ng} / \mathrm{mL}$ in those in whom the headache did not change. There was a significant difference among the median PRL of the groups ( $\mathrm{p}=0.003$ ), between those with headache resolution and those with unchanged headache $(\mathrm{p} \leq 0.001)$ and between partial headache resolution and unchanged headache $(\mathrm{p}=0.022)$. 
Among the patients with tension-type headache phenotype, four had complete resolution of the problem and two partial resolutions; among the patients with migraine phenotype, 10 had complete resolution and 10 partial; among the patients with not classified headache, three had complete and one partial resolution.

Among the 8 patients with idiopathic hyperprolactinemia and headache, two of them used DA agonist, one of them showed complete resolution of the pain, and the other partial recovering. Among those who were not treated, just one presented a partial resolution, showing spontaneous PRL normalization.

Table shows the individual variation in the reduction of PRL level during reevaluation. Among the patients with complete headache resolution, the average decrease on PRL levels was $89.1 \%$, among the patients with a partial resolution was $85.5 \%$, and among those in whom the headache did not change was $40.6 \%$. The difference in the reduction of PRL values between the first two subgroups is not significant, but among the patients with complete or partial headache resolution and the patients with unchanged pain, it was significantly different $(\mathrm{p}<0.001)$.

\section{DISCUSSION}

Prolactin is associated to immune modulation, osmoregulation, personal behavior and metabolism, and has been implicated in the etiology of headache. The hypothalamus, vital to adjust PRL levels, could be involved in the onset of headache, as suggested by the occurrence of premonitory symptoms related to hypothalamic dysfunction in migraine (polyuria, polydipsia, food craving, mood disturbance) ${ }^{5}$, by the relation between menstrual cycle and migraine; and by the involvement of the trigeminovascular system and the presence of hypothalamic nociceptive peptides as neuropeptide $\mathrm{Y}$, vasoactive intestinal polypeptide, among others ${ }^{9-11}$.

Headache is frequent in several hypophyseal tumor phenotypes, varying from 33 to $72 \%$, according to Abe et al. ${ }^{4}$, and 11 to $73 \%$ according to Siegel et al. ${ }^{12}$. Among the possible causes are the local traction of the dura mater; the cavernous sinus invasion, with stimulus to structures sensitive to pain; hormonal hypersecretion of GH or PRL; the rise in intrasellar pressure; the predisposition of the patient and family history $^{2-5}$. The precise mechanisms remain unknown ${ }^{13}$. Among the tumors, the higher prevalence of headache is in the prolactinomas, varying from 37 to $83 \%^{3-14}$.

Studies on the association between hyperprolactinemia and headache are scarce, with predominance of isolated case reports $^{5-16}$, cross-sectional studies with limited samples ${ }^{2-17}$. Besides that, when the headache progression is evaluated, the studies mention the "post-treatment" condition or "PRL normalization" and not the specific correlation between headache and the PRL level.
In the present study, patients with hyperprolactinemia showed headache prevalence of $64.7 \%$, with a predominance of migraine phenotype and tension-type headache phenotype, independent of tumor volume, which is in agreement with the literature. The majority of patients received treatment for hyperprolactinemia with DA agonist and, in some cases, surgical intervention, while others were monitored without intervention. At the time of the reevaluation, the PRL was normalized in $55 \%$ of the cases. Of the patients with headache, $75 \%$ showed complete or partial resolution of the pain.

Headache resolving after treatment of pituitary tumors, including prolactinomas, was observed with surgical treatment ${ }^{4}$ as well as with DA agonist drugs ${ }^{14}$. Levy et al. ${ }^{14}$ reported decreased pain in $25 \%$ of the cases under DA agonist use. Cavestro et al. ${ }^{10}$ observed good responses of the headache to cabergoline in 7 patients with hyperprolactinemia, from a total sample of 27 patients. Bosco et al. ${ }^{17}$, monitoring 29 patients with PRL secreting microadenomas, observed headache improvement using cabergoline, even with PRL levels after treatment equal to $74 \mathrm{ng} / \mathrm{mL}$. Kallestrup et al. ${ }^{11}$ related the same results using DA agonists with no association between headache relief and tumor reduction or PRL normalization $^{11}$. On the other hand, the DA agonists can have a paradoxical effect, once there are cases where its use led to a headache increase ${ }^{5}$.

The results of this study supports the hypothesis that the positive effect on headache is independent of PRL normalization, as observed by Kallestrup et al. ${ }^{11}$, but it is related to PRL reduction.

It was already suggested that pain relief in the case of idiopathic hyperprolactinemia can reflect the pharmacological effect of DA agonists, due to its similar properties to ergot alkaloids, which are present in the trigeminovascular system, or due to its influence in the pain process ${ }^{11}$. In this sample, it was observed pain recovering in three cases of idiopathic hyperprolactinemia, two of them using DA agonists and one not, all showing reduction in the PRL level. The small number of idiopathic cases prevents conclusions, although the findings reinforce the PRL role and not direct effect of the drug.

This study has limitations, especially in relation to the size of sample, and also due to the lack of pairing of the headache treatments that were being used by the patients at the study entry. Despite these considerations, we suggest that in hyperprolactinemic patients the reduction (not necessarily normalization) in the PRL level, regardless of the therapeutic modality, is closely related to the improvement or disappearance of headache. To be confirmed, this fact should be taken into account in the individual therapeutic approach, since it suggests the necessity of a more rigorous control of the PRL levels also in those patients who did not have PRL secreting macroadenomas, in addition to reaching the required level to avoid clinical repercussion in the gonadal axis. 


\section{References}

1. Forsyth PA, Posner JB. Headaches in patients with brain tumors: a study of 111 patients. Neurology. 1993 Sep;43(9):1678-83. https://doi. org/10.1212/wnl.43.9.1678

2. Levy MJ, Jager HR, Powell M, Matharu MS, Meeran K, Goadsby PJ. Pituitary volume and headache: size is not everything. Arch Neurol. 2004 May;61(5):721-5. https://doi.org/10.1001/archneur.61.5.721

3. Gondim JA, de Almeida JP, de Albuquerque LA, Schops M, Gomes E, Ferraz T. Headache associated with pituitary tumors.J Headache Pain. 2009 Feb;10(1):15-20. https://dx.doi.org/10.1007\%2 Fs10194-008-0084-0

4. Abe T, Matsumoto K, Kuwazawa J, Toyoda I, Sasaki K. Headache associated with pituitary adenomas. Headache. 1998 Nov-Dec;38(10):782-6. https://doi.org/10.1046/j.15264610.1998.3810782.x

5. Levy MJ, Matharu MS, Goadsby PJ. Prolactinomas, dopamine agonists and headache: two case reports. Eur J Neurol. 2003 Mar;10(2)169-73. https://doi.org/10.1046/j.1468-1331.2003.00549.x

6. Diogenes A, Patwardhan AM, Jeske NA, Ruparel NB, Goffin V, Akopian $A N$, et al. Prolactin modulates TRPV1 in female rat trigeminal sensory neurons. J Neurosci. 2006 Aug;26(31):8126-36. https://doi. org/10.1523/JNEUROSCI.0793-06.2006

7. International Headache Society (IHS): Headache Classification Committee of The International Classification of Headache Disorders, 3rd edition (beta version) (ICHD-3 beta). Cephalalgia. 2013 Jul;33(9):629-808. https://doi.org/10.1177/0333102413485658

8. Melmed S, Casanueva FF, Hoffman AR, Kleinberg DL, Montori VM, Schlechte JA, et al. Diagnosis and Treatment of Hyperprolactinemia: An Endocrine Society Clinical Practice Guideline. J Clin Endocrinol Metab. 2011 Feb;96(2):273-88. https://doi.org/10.1210/jc.2010-1692

9. Maniyar FH, Sprenger T, Monteith T, Schankin C, Goadsby PJ. Brain activations in the premonitory phase of nitroglycerin-triggered migraine attacks. Brain. 2014 Nov;137(1):232-41. https://doi. org/10.1093/brain/awt320

10. Cavestro C, Rosatello A, Marino MP, Micca G, Asteggiano G. High prolactin levels as worsening factor for migraine. J Headache Pain. 2006 Mar;7:83-9. https://doi.org/10.1007/s10194-006-0272-8

11. Kallestrup MM, Kasch H, Østerby T, Nielsen E, Jensen TS, Jørgensen JOL. Prolactinoma-associated headache and dopamine agonist treatment. Cephalalgia. 2014 Dec;34(7):493-502. https://doi. org/10.1177/0333102413515343

12. Siegel S, Carneiro RW, Buchfelder M, Kleist B, Grzywotz A, Buslei R, et al. Presence of headache and headache types in patients with tumors of the sellar region - can surgery solve the problem? Results of a prospective single center study. Endocrine. 2017 May;56(2):32535. https://doi.org/10.1007/s12020-017-1266-9

13. Levy MJ. The association of pituitary tumors and headache. Curr Neurol Neurosci Rep. 2011 Apr;11(2):164-70. https://doi.org/10.1007/ s11910-010-0166-7

14. Levy MJ, Matharu MS, Meeran K, Powell M, Goadsby PJ. The clinical characteristics of headache in patients with pituitary tumours. Brain. 2005 Aug;128(8):1921-30. https://doi.org/10.1093/brain/awh525

15. De Pue A, Lutin B, Paemeleire K. Chronic cluster headache and the pituitary gland.J Headache Pain. 2016 Mar;17:23-6. https://dx.doi.org /10.1186\%2Fs10194-016-0614-0

16. Andereggen L, Mono ML, Kellner-Weldon F, Christ E. Cluster headache and macroprolactinoma: case report of a rare, but potential important causality. J Clin Neurosci. 2017 Jun;40:62-4. https://doi.org/10.1016/j.jocn.2017.01.028

17. Bosco D, Belfiore A, Fava A, De Rose M, Plastino M, Ceccotti C, et al. Relationship between high prolactin levels and migraine attacks in patients with microprolactinoma. J Headache Pain. 2008 Feb;9(2):103-7. https://doi.org/10.1007/s10194-008-0016-z 